\title{
Hydration characteristics of lithium, zinc, potassium and sodium salts
}

\author{
E. Lefebvre ${ }^{1}$, S. Bennici ${ }^{1}$, E. Gagnière ${ }^{2}$, D. Mangin ${ }^{2}$, and A. Auroux ${ }^{1}$ \\ ${ }^{1}$ Université de Lyon 1, CNRS, UMR 5256, IRCELYON, Institut de recherches sur la catalyse et l'environnement de \\ Lyon, 2 avenue Albert Einstein, F-69626 Villeurbanne, France \\ ${ }^{2}$ Université de Lyon 1, CNRS, UMR 5007, LAGEP, Laboratoire d'automatique et de génie des procédés, CPE Lyon, 43 \\ boulevard du 11 Novembre 1918, 69100 Villeurbanne, France
}

\section{Introduction}

A new inter-seasonal process for storing solar energy is based on absorption of water by a saline solution [1]. For this purpose, many salt hydrates proposed for thermal energy storage application have been studied. In a previous study [2, 3], it was proved that crystallization of the solution inside a storage tank was necessary to increase the storage density, and thus reduce the storage tank size and cost. Crystallization is possible due to a little circulation of fluid in the tank [4] and it must be reversible and controlled.

Enhancement of the storage capacity can be the increase of the mass fraction of absorbent in the concentrated solution. Another criterion taken into account in this process is the appearance (size and form) of the crystals which can impact on the design of the storage tank. As a consequence, the salt needs to be in an anhydrous or at least monohydrate form at the crystallization temperature $(278 \mathrm{~K})$. The first salt chosen for the system was lithium bromide. It presents interesting thermal properties. However, $\mathrm{LiBr}$ crystallizes in dihydrated form at the temperature of the storage tank surrounding $\left(5-10^{\circ} \mathrm{C}\right)$ with a water content of $29 \mathrm{wt} \%$ of water [2-5]. In view of replacement of $\mathrm{LiBr}$, it was selected six other salts according to their literature data on their hydrated forms at low temperature, their solubility in water and their low price. These salts are lithium chloride, zinc bromide, potassium hydroxide, potassium formate, sodium hydroxide and sodium thiocyanate. Lithium chloride is a well-known desiccant salt principally used in absorption system for cooling and dehumidification [6]. Because of their good thermal properties, potassium formate and sodium hydroxide were previously studied respectively as a secondary refrigerant in an aqueous solution [7] and as the sorbent in a long term heat storage process. Flamensbeck [8] associated potassium hydroxide with sodium hydroxide to replace lithium bromide in absorption chiller. Eventually, sodium thiocyanate was generally combined with ammonia to create the couple absorbent/absorbate as a refrigerant in absorption cooling system [9].
In this work, hydration characteristics, enthalpies and transition temperature, of these seven salts, were determined using a thermogravimetry analysis (TG) and differential scanning analysis (DSC). Results of these experiments were compared to those of lithium bromide.

\section{Experimental}

\subsection{Samples preparation}

Anhydrous salts were purchased from Alfa $(\mathrm{LiBr}, \mathrm{KOH}$ and $\mathrm{NaOH}$ ) or Sigma Aldrich ( $\mathrm{LiCl}, \mathrm{ZnBr}_{2}, \mathrm{KCHO}_{2}$ and $\mathrm{KSCN}$ ) with purity between $99.9 \%$ and $99.99 \%$.

Hydrated salts were prepared from anhydrous salts at room temperature. For all salts except $\mathrm{ZnBr}_{2}$, the hydrated forms were prepared under a saturated water atmosphere which was created by a hermetical batch containing a little amount of water. The water composition of the salts was regularly followed by mass variation in order to obtain a stable hydrated form in accordance with theoretical data. This method was used to create the hydrated salts presented in Table 1 .

Because of its high kinetics of hydration, the di hydrated form of zinc bromide was obtained by precipitation. The anhydrous salt was solubilised in water at $323 \mathrm{~K}$ and crystallised at room temperature. The solution was filtered and dried at $298 \mathrm{~K}$. All hydrated salts were kept in a desiccator over silica gel and then analysed both by TG and DSC.

Table 1. Hydrated form of the prepared salts.

\begin{tabular}{rr}
\hline \multicolumn{1}{r}{ Salt } & Hydrates formed \\
\hline $\mathrm{LiBr}$ & $\mathrm{LiBr} .2 \mathrm{H}_{2} \mathrm{O}$ \\
$\mathrm{LiCl}$ & $\mathrm{LiCl} . \mathrm{H}_{2} \mathrm{O}$ \\
$\mathrm{KOH}$ & $\mathrm{KOH} \cdot 2 \mathrm{H}_{2} \mathrm{O}$ \\
$\mathrm{KCHO}_{2}$ & $\mathrm{KCHO}_{2} . \mathrm{H}_{2} \mathrm{O}$ \\
$\mathrm{NaOH}$ & $\mathrm{NaOH}_{2} \mathrm{H}_{2} \mathrm{O}$ \\
$\mathrm{NaSCN}$ & $\mathrm{NaSCN}_{2} 2 \mathrm{H}_{2} \mathrm{O}$ \\
$\mathrm{ZnBr}_{2}$ & $\mathrm{ZnBr}_{2 .} 2 \mathrm{H}_{2} \mathrm{O}$ \\
\hline
\end{tabular}




\subsection{DSC analysis}

DSC measurements were carried out with a DSC Q100 from TA Instruments. Data were integrated from the recorded output computational software. The instrument was calibrated and tested with a high purity indium metal. Due to their high ability to absorb moisture when exposed to air, the samples were loaded and sealed quickly. About 1 to $5 \mathrm{mg}$ of salts were introduced into an aluminium sealed-type DSC pan. A hole of c.a. $0.5 \mathrm{~mm}$ in diameter was made in the top of the sealed pan to evacuate the water evolved during the dehydration. The flow of dry nitrogen was maintained constant at 50 $\mathrm{cm}^{3} / \mathrm{min}$ to get a stationary vaporization [10].

Samples were heated from $274 \mathrm{~K}$ to either $473 \mathrm{~K}$ or $573 \mathrm{~K}$ (depending on their melting temperature) with a heating rate of $5 \mathrm{~K} / \mathrm{min}$. This temperature was maintained one minute and then samples were cooled to $274 \mathrm{~K}$ at 15 $\mathrm{K} / \mathrm{min}$. Endoh [10] explained that a thin film of salt crystallite takes place over sample during heating because of the high enthalpy of vaporization of water which created a temperature gradient on samples. In order to avoid this phenomenon, samples were placed on the pan, uniformly centred and with a very small thickness.

These analyses proved the transition temperatures of hydrated forms and their associated enthalpies.

\subsection{TG analysis}

The TG analyses were performed with a HI RES Modulated TGA2950 TG Analyzer from TA Instruments. The temperature calibration was made with a high purity indium sample by correspondence with its Curie temperature.

Around $5 \mathrm{mg}$ of sample were quickly placed into an opened platinum pan and immediately analysed. The flow rate of dry nitrogen was $90 \mathrm{~cm}^{3} / \mathrm{min}$. In order to compare these data with DSC analyses, the samples were heated to $473 \mathrm{~K}$ or $573 \mathrm{~K}$ with a rate of $5 \mathrm{~K} / \mathrm{min}$. The data allowed to determine the loss of water corresponding to each transition observed in DSC.

\section{Results}

TG and DSC results were treated simultaneously for all samples. The temperature transitions observed by DSC are very similar to those determined by TG analysis. The results for all salts are reported in Table 2.

Two different transitions were observed for lithium bromide corresponding to the transitions $\mathrm{LiBr} .2 \mathrm{H}_{2} \mathrm{O} / \mathrm{LiBr} . \mathrm{H}_{2} \mathrm{O}$ and $\mathrm{LiBr} . \mathrm{H}_{2} \mathrm{O} /$ anhydrous $\mathrm{LiBr}$. Apelblat [11], by analysis of the phase diagram of the (lithium bromide + water) system, determined a temperature " $\mathrm{T}_{\text {literature }}$ corresponding to the different forms of $\mathrm{LiBr}$ in equilibrium with their saturated aqueous solution. These literature temperatures are reported also on Table 2.

Transition temperatures are in good agreement with the literature. Moreover, the enthalpies of transition of the hydrated forms were calculated by integrating the peaks on DSC plot.
A little exothermic peak without any mass variation is observed by DSC near $305 \mathrm{~K}$. It is due to an $\alpha \rightarrow \beta$ transformation of $\mathrm{LiBr}_{2} \mathrm{H}_{2} \mathrm{O}$, as indicated on the phase diagram [10].

The transition temperature of $\mathrm{LiCl} \cdot \mathrm{H}_{2} \mathrm{O}$ into anhydrous $\mathrm{LiCl}$ is $363 \mathrm{~K}$ in agreement with that given by the phase diagram of $\left(\mathrm{LiCl}+\mathrm{H}_{2} \mathrm{O}\right)$ [12] and Apelblat [13].

The phase diagram of potassium hydroxide - water [14] and sodium hydroxide-water [7] presented different hydrated transition temperatures. These values were compared to the transition temperatures determined by TG analysis of $\mathrm{KOH} .2 \mathrm{H}_{2} \mathrm{O}$ and $\mathrm{NaOH} . \mathrm{H}_{2} \mathrm{O}$. DSC confirmed the temperature values presented in Table 2 . It can be noticed that enthalpies corresponding to the transition between monohydrate and anhydrous forms is the same for both hydroxide salts.

Transition temperature of $\mathrm{NaSCN}-\mathrm{NaSCN} .2 \mathrm{H}_{2} \mathrm{O}$ was compared to data given by Nyvlt [15]. He assessed that this temperature corresponded to the transition between the dihydrate and anhydrous forms. Our measured temperature corresponded to this transition and is in good accordance with the data given by Nyvlt.

Little information is available on the properties of the hydrated forms of potassium formate which prevented us from a comparison with literature data.

Table 2. TG and DSC results for all salts.

\begin{tabular}{|c|c|c|c|c|}
\hline \multirow[t]{2}{*}{$\begin{array}{c}\text { Forms of } \\
\text { salts }\end{array}$} & \multicolumn{3}{|c|}{$\begin{array}{l}\text { Transition temperature } \\
\text { during heating }(\mathrm{K})\end{array}$} & \multirow[t]{2}{*}{$\begin{array}{c}\Delta \mathbf{H} \\
(\mathrm{J} / \mathrm{g})\end{array}$} \\
\hline & \multicolumn{2}{|c|}{$\mathrm{T}_{\text {literature }}$} & $\mathrm{T}_{\mathrm{exp}}$ & \\
\hline $\mathrm{LiBr}$ & $>432[11]:$ & & 434 & 32 \\
\hline $\mathrm{LiBr}^{\mathrm{H}} \mathrm{H}_{2} \mathrm{O}$ & $316[11]$ & 313 [15] & 315 & 31 \\
\hline $\mathrm{LiBr} .2 \mathrm{H}_{2} \mathrm{O}$ & $<281[11]$ & 277 [15] & - & - \\
\hline $\mathrm{LiCl}$ & 373 [13] & 369 [15] & 367 & 89 \\
\hline $\mathrm{LiCl}_{\mathrm{H}} \mathrm{H}_{2} \mathrm{O}$ & 293 [12] & $292[15]$ & - & - \\
\hline $\mathrm{LiCl} .2 \mathrm{H}_{2} \mathrm{O}$ & & & - & - \\
\hline $\mathrm{KOH}$ & $372[14]$ & & 375 & 78 \\
\hline $\mathrm{KOH} . \mathrm{H}_{2} \mathrm{O}$ & 306 [14] & 306 [15] & 313 & - \\
\hline $\mathrm{KOH} .2 \mathrm{H}_{2} \mathrm{O}$ & $240[14]$ & & - & - \\
\hline $\mathrm{NaOH}$ & 335 [7] & 335 [15] & 337 & 78 \\
\hline $\mathrm{NaOH} . \mathrm{H}_{2} \mathrm{O}$ & 285 [7] & 285 [15] & - & - \\
\hline $\mathrm{NaOH} .2 \mathrm{H}_{2} \mathrm{O}$ & 278 [7] & & - & - \\
\hline $\mathrm{NaOH} \cdot 3.5 \mathrm{H}_{2} \mathrm{O}$ & 277 [7] & $278[15]$ & - & - \\
\hline $\begin{array}{l}\mathrm{KCHO}_{2} \\
\mathrm{KCHO}_{2} \cdot \mathrm{H}_{2} \mathrm{O}\end{array}$ & & & $\begin{array}{c}438 \\
-\end{array}$ & $\begin{array}{c}63 \\
-\end{array}$ \\
\hline $\begin{array}{l}\mathrm{ZnBr}_{2} \\
\mathrm{ZnBr}_{2} \cdot 2 \mathrm{H}_{2} \mathrm{O}\end{array}$ & & 308 [15] & $\begin{array}{c}304 \\
-\end{array}$ & $\begin{array}{c}14 \\
-\end{array}$ \\
\hline $\mathrm{NaSCN}$ & & 303 [15] & 309 & 56 \\
\hline $\mathrm{NaSCN} .2 \mathrm{H}_{2} \mathrm{O}$ & & & - & - \\
\hline
\end{tabular}

\section{Conclusion}

Firstly, transition enthalpy between hydrated and anhydrous forms indicated the strength of interaction between solute and water. The lowest is this enthalpy; the most convenient is the salt in the process. Transition enthalpy of lithium chloride between monohydrate and 
anhydrous forms is deeply higher than that of lithium bromide.

Secondly, according to the hydrated form of salts, the mass fraction of water in the storage tank can be calculated. Figure 1 shows water content of the solution in the storage tank at $278 \mathrm{~K}$ and room temperature for the seven salts.

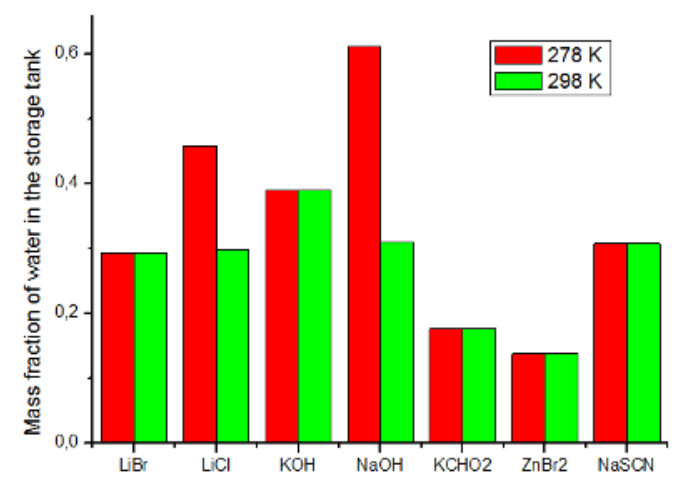

Figure 1. Water content of the solution in the storage tank for all salts at $278 \mathrm{~K}$ and $298 \mathrm{~K}$.

In the light of these results, zinc bromide and potassium formate are the most suitable sample for the process. Both solutions in the storage tank reach the lowest water content, $14 \mathrm{wt} \%$ for $\mathrm{ZnBr}_{2}$ and $18 \mathrm{wt} \%$ for $\mathrm{KCHO}_{2}$. Besides, they present low transition temperature and associated enthalpy. Moreover, potassium hydroxide and sodium thiocyanate present small mass fraction of water in the solution but a high transition enthalpy can be noticed. No enhancement on the storage capacity can be realized with lithium chloride and sodium hydroxide which mass fractions of water are respectively 30 and 31 wt $\%$. Zinc bromide seems to be the most performing salt which can be used in the inter-seasonal process.

\section{References}

1. H. Lui, Ph.D. dissertation, University of Savoie, 2010

2. K.E. N'Tsoukpoe, N. Le Pierrès, L. Luo, Energy 37 346 (2012)

3. P. Tatsidjodoung, N. Le Pierrès, L. Luo, Renewable and Sustainable Energy Reviews 18327 (2013)

4. L. Hui, K.E. N'Tsoukpoe, N. Le Pierrès, L. Luo Energy Conversion and Management 522427 (2011)

5. K.E. N'Tsoukpoe, N. Le Pierrès, Energy Procedia 30 331 (2012)

6. C. Bales, Laboratory prototypes of thermo-chemical and sorption storage units, Report B3-Task 32 (2007). Available from:

http://www.iea-

shc.org/publications/downloads/task32-

Laboratory_Prototypes_of

Chemical_and_Sorption_Storage_Units.pdf

7. R. Weber, V. Dorer, Vacuum 82708 (2008)

8. M. Flamensbeck, F. Summerer, P. Riesch, F. Ziegler, G. Alefeld, Applied Thermal Engineering 18413 (1998)

9. A. Acuna, N. Velazquez, J. Cerezo, Applied Thermal Engineering 511273 (2013)
10. K. Endoch, H. Suga, Thermochimica Acta 327133 (1999)

11. A. Apelblat, A. Tamir, Journal of Chemical Thermodynamics 18201 (1986)

12. J. Patek, J. Klomfar, Fluid Phase Equilibria 250138 (2006)

13. A. Apelblat, R. Weintraub, A. Tamir, Journal of Chemical Thermodynamics 16935 (1984)

14.W.M. Vogel, K.J. Routsis, V.J. Kehrer, D.A. Landsman, J.G. Tschinkel, Journal of Chemical and Engineering Data 12465 (1967)

15. J. Nyvlt, Solid-Liquid Phase Equilibria, Elsevier Scientific Publishing Company, New York (1977) 